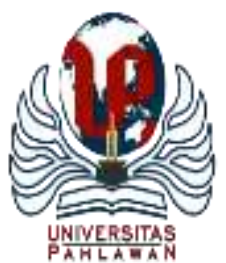

Edukatif : Jurnal Ilmu Pendidikan Volume 3 Nomor 6 Tahun 2021 Halm 4738 - 4749

EDUKATIF: JURNAL ILMU PENDIDIKAN

Research \& Learning in Education

https://edukatif.org/index.php/edukatif/index

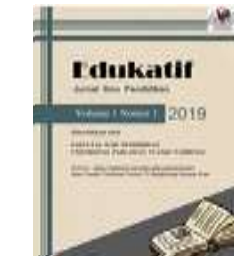

\title{
Analisis Miskonsepsi Menggunakan Four Tier Diagnostic Test Berbantuan Google Form pada Materi Tekanan Zat
}

\author{
Windi Oktaviani Putri ${ }^{1 凶}$, Haratua Tiur Maria ${ }^{2}$, Hamdani $^{3}$ \\ Universitas Tanjungpura, Indonesia ${ }^{1,2,3}$ \\ E-mail : windieoktaviani@gmail.com ${ }^{1}, \underline{\text { haratuatiur67@gmail.com }}^{2}, \underline{\text { hamdani052185@gmail.com }}^{3}$
}

\begin{abstract}
Abstrak
Penelitian ini bertujuan untuk menyelidiki konsepsi dan miskonsepsi peserta didik pada materi tekanan zat dan perbedaan miskonsepsi antara peserta didik laki-laki dengan perempuan. Penelitian ini merupakan penelitian kualitatif deskriptif. Penelitian ini dilaksanakan di SMP Negeri 2 Nanga Pinoh. Sampel dalam penelitian ini berjumlah 127 orang terdiri dari 53 orang peserta didik laki-laki dan 73 orang peserta didik perempuan. Teknik pengumpulan data dilakukan dengan pemberian tes diagnostik four tier berbantuan google form kepada peserta didik kelas VIII. Analisis data penelitian ini dilakukan dengan langkah reduksi data, penyajian data, dan penarikan kesimpulan. Hasil penelitian menunjukkan bahwa hasil miskonsepsi paling tinggi pada nomor soal 8 sebesar $45 \%$ dengan indikator mengidentifikasi pengaruh banyaknya zat cair pada kedudukan benda, sedangkan miskonsepsi terendah pada nomor soal 1 sebesar $14 \%$ dengan indikator mengidentifikasi pengaruh luas penampang benda yang berbeda terhadap tekanan yang dihasilkan. Persentase rata-rata peserta didik yang mengalami miskonsepsi sebesar 30\% dan termasuk dalam kategori rendah. Serta tidak ada perbedaan miskonsepsi antara peserta didik laki-laki dan perempuan. Dengan nilai chi kuadrat hitung $(5,892)$ lebih kecil dari nilai chi kuadrat tabel $(16,919)$.
\end{abstract}

Kata kunci: Analisis Miskonsepsi, Four Tier Diagnostic Test berbantuan Google Form, Perbedaan Miskonsepsi berdasarkan Gender.

\begin{abstract}
This study aims to investigate the conceptions and misconceptions of students on the subject of substance pressure and the differences in misconceptions between male and female students. This research is a descriptive qualitative research. This research was conducted at SMP Negeri 2 Nanga Pinoh. The sample in this study amounted to 127 people consisting of 53 male students and 73 female students. The data collection technique was carried out by giving four tier diagnostic tests with the help of google form to class VIII students. The data analysis of this research was carried out by means of data reduction, data presentation, and drawing conclusions. The results showed that the highest misconception in question number 8 was 45\% with indicators identifying the effect of the amount of liquid on the position of objects, while the lowest misconceptions in question number 1 was $14 \%$ with indicators identifying the effect of different cross-sectional areas on the resulting pressure. The average percentage of students who experience misconceptions is $30 \%$ and is included in the low category. And there is no difference in misconceptions between male and female students. With the calculated chi squared value (5.892) smaller than the table chi square value (16.919).
\end{abstract}

Keywords: Misconception Analysis, Four Tier Diagnostic Test assisted by Google Form, Differences in Misconceptions based on Gender.

Copyright (c) 2021 Windi Oktaviani Putri, Haratua Tiur Maria, Hamdani

$\triangle$ Corresponding author

Email : windieoktaviani@gmail.com

DOI : https://doi.org/10.31004/edukatif.v3i6.1445

ISSN 2656-8063 (Media Cetak)

ISSN 2656-8071 (Media Online)

Edukatif : Jurnal Ilmu Pendidikan Vol 3 No 6 Tahun 2021 p-ISSN 2656-8063 e-ISSN 2656-8071 
4739 Analisis Miskonsepsi Menggunakan Four Tier Diagnostic Test Berbantuan Google Form pada Materi Tekanan Zat - Windi Oktaviani Putri, Haratua Tiur Maria, Hamdani

DOI: https://doi.org/10.31004/edukatif.v3i6.1445

\section{PENDAHULUAN}

Pendidikan merupakan proses pembekalan diri pada manusia yang dapat memberikan sebuah pengalaman zaman. Pendidikan tidak lepas dari pembelajaran. Bagi mereka yang dapat menyampaikan konsep waktu, pendidikan adalah proses yang mandiri. Pendidikan tidak dapat dipisahkan dari pembelajaran. Pembelajaran adalah proses interaktif antara peserta didik dengan guru dan lingkungan belajar untuk mencapai tujuan memperoleh pengetahuan, yang diterapkan dalam sistem pendidikan Indonesia.

Pembelajaran IPA khususnya fisika, menurut kurikulum 2013 bertujuan untuk memberikan kesempatan kepada peserta didik untuk menginternalisasikan konsep dan prinsip fisika serta kemampuan untuk mengembangkan ilmu pengetahuan dan mata pelajaran yang dapat dipercaya untuk melanjutkan ke jenjang yang lebih tinggi dan pengembangan ilmu pengetahuan dan teknologi (Nurulwati \& Rahmadani, 2019).

Pemahaman adalah hasil dari pembelajaran, ada indikator dimana setiap orang dapat menjelaskan atau mendefiniskan suatu informasi dengan kata-katanya sendiri. Pemahaman konseptual ditujukan untuk memahami secara benar proses tindakan atau ide abstrak yang dapat mengklasifikasikan objek atau peristiwa, dan mewujudkan pemahaman konsep melalui pembelajaran (Elisa et al., 2017). Permasalahanya adalah peserta didik sering mengalami kesalahan konseptual atau miskonsepsi dalam proses pembelajaran, bahkan jika pembelajaran sudah disampaikan oleh guru. Pengetahuan peserta didik biasanya tidak lengkap, karena fisika terdiri dari konsep dan prinsip yang sangat abstrak dan kompleks (Arifin, 2017).

Salah satu cara untuk mengetahui miskonsepsi pada peserta didik adalah dengan tes diagnostik. Tes diagnostik sengaja dirancang untuk mengetahui kesulitan belajar peserta didik, termasuk miskonsepsi yang dialami peserta didik. Four-Tier Diagnostic Test merupakan tes diagnostik yang dimodifikasi dari Three-Tier Diagnostic Test. Beberapa bentuk tes diagnostik pilihan ganda di antaranya: tes diagnostik pilihan ganda onetier (satu tingkat), two-tier (dua tingkat), three-tier (tiga tingkat), dan four-tier (empat tingkat). Tes diagnostik pilihan ganda satu tingkat menyajikan beberapa pilihan jawaban yang harus dipilih peserta didik. Keunggulan yang dimiliki tes diagnostik empat tingkat adalah guru dapat: 1) membedakan tingkat keyakinan jawaban dan tingkat keyakinan alasan yang dipilih peserta didik sehingga dapat menggali lebih dalam mengenai miskonsepsi peserta didik, 2) membuat diagnosis yang lebih dalam dari miskonsepsi yang dihadapi peserta didik, 3) mengidentifikasi bagian-bagian materi yang memerlukan perhatian lebih, 4) merencanakan pembelajaran yang lebih efektif untuk mengatasi miskonsepsi peserta didik (Sheftyawan et al., 2018).

Four Tier Diagnostic Test menghasilkan berbagai macam data, sehingga rentan terhadap kesalahan input dan memakan waktu. Penggunaan Google Forms dapat dijadikan sebagai solusi untuk masalah ini. Menurut Hamdani (Irmaya \& Sunarti, 2020), Google Forms adalah salah satu layanan yang disediakan oleh Google untuk mengelola pendaftaran acara, pemungutan suara, pembuatan kuesioner, dan survei online. Google Forms akan secara otomatis menyimpan jawaban peserta didik dan dapat memuatnya sebagai dokumen Excel.

Konsepsi peserta didik juga dipengaruhi oleh gender. Sejumlah penelitian menunjukkan bahwa pria rentan terhadap sikap agresif, semangat arogan, matematika dan keterampilan alami, dan kemampuan berpikir yang lebih kompleks. Pada saat yang sama, wanita cenderung lebih termotivasi untuk mencapai tujuan tertentu (Mahanal, 2012). Perbedaan antara peserta didik laki-laki dan perempuan dalam banyak hal mengakibatkan perbedaan metode penalaran di antara mereka. Berbagai proses penerimaan, interpretasi atau perubahan konseptual yang berbeda pula. Meninjau hal tersebut maka perlu dilakukan identifikasi, terutama konsepsi dan berpikir kritis peserta didik, yang berkaitan dengan gender.

Berdasarkan hasil wawancara dengan guru IPA di SMP Negeri 2 Nanga Pinoh, Nita Yulianti, S.Si, beliau mengatakan bahwa mengetahui miskonsespsi pada pembelajaran tekanan zat masih dirasakan cukup sulit. Guru hanya menggunakan praktikum sederhana, belum pernah membuat tes diagnostik untuk 
mengetahui miskonsepsi peserta didik. Guru juga menyebutkan bahwa hasil nilai ulangan materi tekanan zat kebanyakan masih mendapatkan nilai rendah.

Meskipun banyak penelitian yang meneliti miskonsepsi peserta didik pada materi tekanan zat beserta faktor penyebab miskonsepsi, namun belum banyak yang meneliti miskonsepsi peserta didik menggunakan Four Tier Diagnostic Test berbantuan Google Form. Penelitian ini bermaksud menyelidiki miskonsepsi dan faktor penyebab nya, khususnya di SMP Negeri 2 Nanga Pinoh. Melalui penelitian ini diharapkan Four Tier Diagnostic Test berbantuan Google Form dapat menganalisis miskonsepsi peserta didik pada materi tekanan zat sehinggaa memudahkan guru menentukan tindakan yang tepat untuk mengatasi miskonsepsi tersebut.

Berdasarkan uraian di atas, dirumusan masalah dalam penelitian ini, yaitu: (1) bagaimana konsepsi peserta didik di SMP Negeri 2 Nanga Pinoh tentang tekanan zat; (2) bagaimana perbedaan miskonsepsi antara peserta didik laki-laki dengan perempuan di SMP Negeri 2 Nanga Pinoh tentang tekanan zat. Penelitian ini bertujuan untuk (1) menyelidiki konsepsi peserta didik yang terjadi pada materi tekanan zat di SMP Negeri 2 Nanga Pinoh; (2) menyelidiki perbedaan miskonsepsi antara peserta didik laki-laki dengan perempuan di SMP Negeri 2 Nanga Pinoh tentang tekanan zat.

\section{METODE PENELITIAN}

Metode penelitian yang digunakan pada penelitian ini adalah penelitian deskriptif dengan metode penelitian kuantitatif. Penelitian deskriptif menurut Sugiyono (2015) adalah penelitian yang digunakan dengan cara mendeskripsikan maupun menggambarkan data yang telah terkumpul sebagaimana adanya tanpa bermaksud membuat kesimpulan yang berlaku untuk umum yang bertujuan untuk menganalisis data. Menurut Sugiyono (2015) metode penelitian kuantitatif dapat diartikan sebagai metode penelitian yang digunakan untuk meneliti pada populasi atau sampel tertentu, teknik pengambilan sampel pada umumnya dilakukan secara random, pengumpulan data menggunakan instrumen penelitian, dengan tujuan untuk menguji hipotesis yang telah ditetapkan.

Populasi dalam penelitian ini adalah peserta didik kelas VIII SMP Negeri 2 Nanga Pinoh tahun ajaran 2020/2021 yang terdiri dari tujuh kelas. Sampel penelitian dalam penelitian ini yaitu kelas VIII A, VIII B, VIII C, VIII D, dan VIII E yang dipilih secara acak dengan Teknik simple random sampling.

Teknik pengumpulan data yang digunakan dalam penelitian ini adalah Teknik tes diagnostik pilihan ganda dengan alasan tertutup yang telah divalidasi oleh 2 orang dosen pendidikan fisika FKIP UNTAN dan 1 orang guru IPA SMP Negeri 2 Nanga Pinoh. Alat pengumpulan data yang digunakan dalam penelitian ini adalah 10 soal Four Tier Diagnostic Test berbantuan Google Form pada materi tekanan zat.

Hasil tes data hasil jawaban peserta didik dianalisis berdasarkan kriteria penilaian bentuk Four-tier Diagnostic test. Merekapitulasi profil konsepsi peserta didik yaitu mengelompokkan jawaban peserta didik yang konsepsi atas dasar kesamaan pilihan alasan dan menghitung persentase jawaban peserta didik dengan rumus:

$$
\%=\frac{\sum N}{N_{t}} \times 100 \%
$$

Keterangan :

$\%$ : Persentase jumlah peserta didik pada setiap kategori.

$\sum N$ : Jumlah peserta didik pada setiap kategori.

$N_{t}$ : Jumlah total peserta didik

Untuk mengetahui perbedaan miskonsepsi antara peserta didik laki-laki dan perempuan, maka dapat dilakukan dengan cara uji chi kuadrat. Menghitung $\mathrm{f}_{\mathrm{h}}$ dengan rumus:

$$
f_{h}=\frac{\text { Jumlah }(X) . \text { Jumlah miskonsepsi pada gender }}{\sum Y}
$$


4741 Analisis Miskonsepsi Menggunakan Four Tier Diagnostic Test Berbantuan Google Form pada Materi Tekanan Zat - Windi Oktaviani Putri, Haratua Tiur Maria, Hamdani

DOI: https://doi.org/10.31004/edukatif.v3i6.1445

Menghitung harga $x^{2}$ dengan rumus :

$$
x^{2}=\sum \frac{\left(f_{0}-f_{h}\right)^{2}}{f h}
$$

(Sugiyono, 2013)

\section{HASIL DAN PEMBAHASAN PENELITIAN}

\section{Hasil}

Dalam proses pengambilan data yang akan di analisis, sampel yang digunakan sebanyak 127 peserta didik yang terdiri dari 53 peserta didik laki-laki dan 74 peserta didik perempuan pada kelas VIII di SMP Negeri 2 Nanga Pinoh. Pengkategorian hasil jawaban peserta didik dibagi menjadi empat kategori sesuai dengan referensi yang digunakan oleh peneliti antara lain, yaitu Miskonsepsi (M), Paham Konsep (PK), Paham Sebagian (PS), dan Tidak Paham Konsep (TPK) disajikan pada gambar .

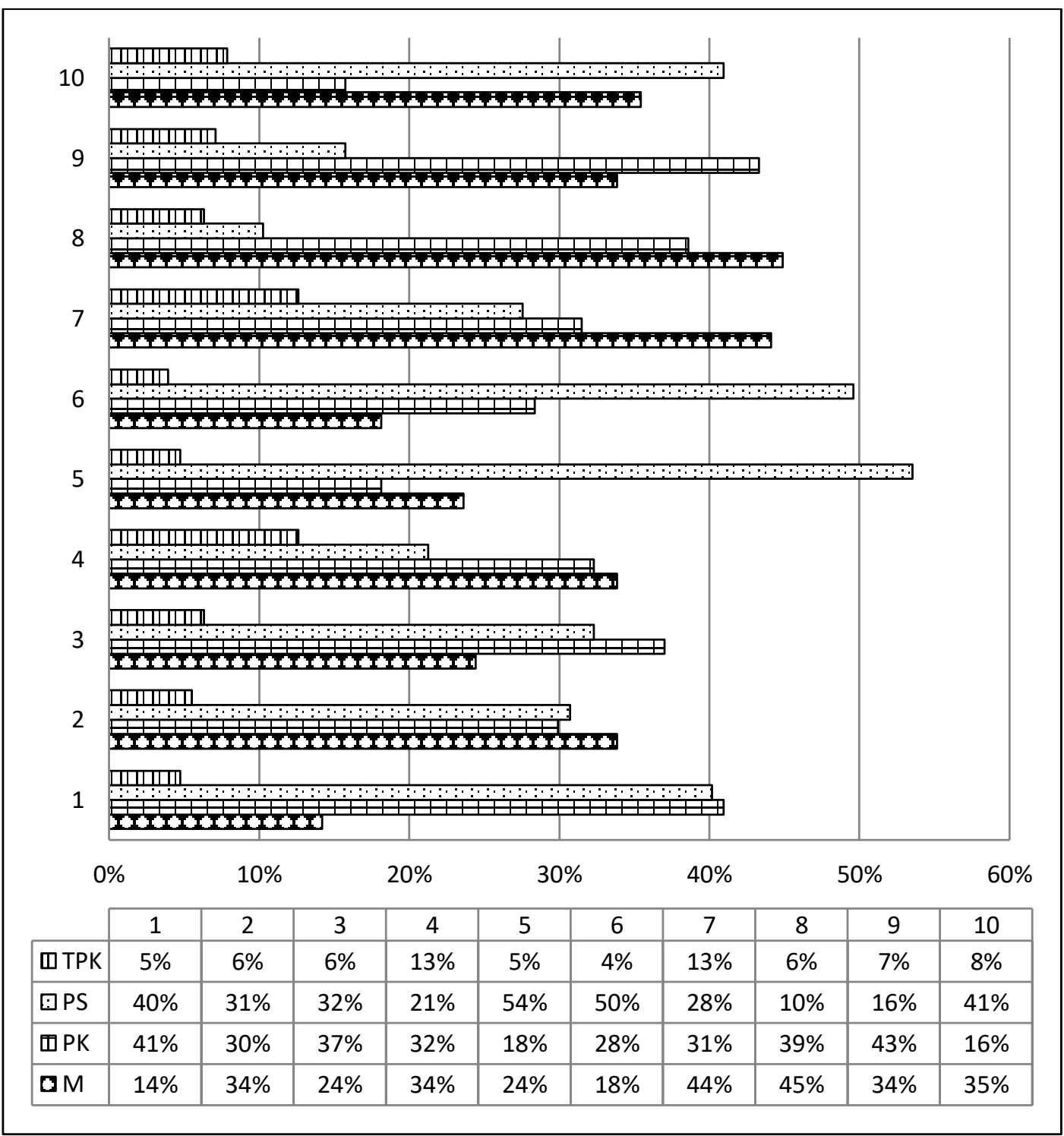

Gambar. Grafik persentase peserta didik yang mengalami Miskonsepsi, Paham Konsep, Paham Sebagian, dan Tidak Paham Konsep. 
4742 Analisis Miskonsepsi Menggunakan Four Tier Diagnostic Test Berbantuan Google Form pada Materi Tekanan Zat - Windi Oktaviani Putri, Haratua Tiur Maria, Hamdani

DOI: https://doi.org/10.31004/edukatif.v3i6.1445

Secara keseluruhan nilai rata-rata peserta didik yang paham konsep yaitu sebesar 32\%. Nilai rata-rata peserta didik tidak paham konsep sebesar 32\%, nilai rata-rata peserta didik yang tidak paham konsep sebesar 7\%. Nilai rata-rata peserta didik yang mengalami miskonsepi sebesar 30\% dan termasuk dalam kategori rendah. Hal tersebut mengacu pada Suwarna (2013) bahwa pengelompokkan miskonsepsi menjadi tiga kategori yaitu 0-30\% (rendah), 31-60\% (sedang), dan 61-100\% (tinggi).

Adapun rekapitulasi konsepsi peserta didik pada materi tekanan zat disajikan pada Tabel 1 dan Tabel 2.

Tabel 1 Profil Konsepsi Peserta Didik yang Benar

\begin{tabular}{|c|c|c|c|}
\hline No & Konsepsi Peserta Didik & $\sum$ & $\%$ \\
\hline 1. & $\begin{array}{l}\text { Luas penampang pada benda A lebih kecil daripada benda B } \\
\text { sehingga tekanan yang diberikan pada benda A lebih besar. }\end{array}$ & 98 & 76,6 \\
\hline 2. & $\begin{array}{l}\text { Tekanan hidrostatis bergantung pada massa jenis fluida, } \\
\text { percepatan gravitasi yang dialami titik, dan kedalaman titik di } \\
\text { dalam fluida. }\end{array}$ & 66 & 51,6 \\
\hline 3. & $\begin{array}{l}\text { Jika kedalaman bejana semakin besar maka tekanan hidrostatis } \\
\text { yang dialami titik pada bejana juga semakin besar tetapi } \\
\text { sebaliknya jika kedalaman bejana semakin kecil maka tekanan } \\
\text { hidrostatis yang dialami titik pada bejana juga semakin kecil. }\end{array}$ & 79 & 61,7 \\
\hline 4. & $\begin{array}{l}\text { Jika kedalaman bejana semakin besar maka tekanan hidrostatis } \\
\text { yang dialami titik pada bejana juga semakin besar tetapi } \\
\text { sebaliknya jika kedalaman bejana semakin kecil maka tekanan } \\
\text { hidrostatis yang dialami titik pada bejana juga semakin kecil. }\end{array}$ & 53 & 41,4 \\
\hline 5. & Gaya yang dihasilkan sebanding dengan tekanan yang diberikan. & 47 & 36,7 \\
\hline 6. & $\begin{array}{l}\text { Jika massa jenis benda lebih besar dari massa jenis fluida maka } \\
\text { benda akan tenggelam. }\end{array}$ & 58 & 45,3 \\
\hline 7. & $\begin{array}{l}\text { Karena tekanan yang bekerja pada fluida di dalam wadah } \\
\text { tertutup akan diteruskan oleh fluida tersebut kesegala arah } \\
\text { dengan sama besar. }\end{array}$ & 48 & 37,5 \\
\hline 8. & Karena gaya apung tidak bergantung pada kedalaman air. & 56 & 43,8 \\
\hline 9. & $\begin{array}{l}\text { Ketika di dalam air berat benda menjadi berkurang karena benda } \\
\text { mendapatkan gaya ke atas (gaya apung) oleh zat cair. }\end{array}$ & 71 & 55,5 \\
\hline 10. & $\begin{array}{l}\text { Besarnya gaya apung bertambah seiring bertambahnya massa } \\
\text { jenis fluida sehingga massa jenis } 1 \text { besar daripada massa jenis } 2 \\
\text { dan massa jenis } 3 \text {. }\end{array}$ & 59 & 46,1 \\
\hline
\end{tabular}

Tabel 2 Konsepsi Peserta Didik yang Tidak Benar

\begin{tabular}{cllc}
\hline No & \multicolumn{1}{c}{ Konsepsi Peserta Didik } & $\sum$ & $\%$ \\
\hline 1. & $\begin{array}{l}\text { Luas penampang pada benda A lebih besar daripada benda B } \\
\text { sehingga tekanan yang diberikan pada benda A lebih besar. }\end{array}$ & 18 & 14,1 \\
\hline $\begin{array}{l}\text { Luas penampang pada benda A dan benda B sama sehingga } \\
\text { tekanan yang diberikan sama. }\end{array}$ & 12 & 9,4 \\
\hline 2. & $\begin{array}{l}\text { Tekanan hidrostatis hanya bergantung pada massa jenis fluida. } \\
\text { Tekanan hidrostatis hanya bergantung pada kedalaman titik di } \\
\text { dalam fluida. }\end{array}$ & 20 & 15,6 \\
\hline $\begin{array}{l}\text { Jika luas penampang bejana semakin besar maka tekanan } \\
\text { hidrostatis yang dialami titik pada bejana juga semakin besar } \\
\text { tetapi sebaliknya jika luas penampang bejana semakin kecil } \\
\text { maka tekanan hidrostatis yang dialami titik pada bejana juga } \\
\text { semakin kecil. }\end{array}$ & 28 & 32,8 \\
\hline $\begin{array}{l}\text { Jika volume bejana semakin besar maka tekanan hidrostatis } \\
\text { yang dialami titik pada bejana juga semakin besar tetapi }\end{array}$ & 21,9 \\
\hline
\end{tabular}


4743 Analisis Miskonsepsi Menggunakan Four Tier Diagnostic Test Berbantuan Google Form pada Materi Tekanan Zat - Windi Oktaviani Putri, Haratua Tiur Maria, Hamdani

DOI: https://doi.org/10.31004/edukatif.v3i6.1445

sebaliknya jika volume bejana semakin kecil maka tekanan

hidrostatis yang dialami titik pada bejana juga semakin kecil.

Jika luas penampang bejana semakin besar maka tekanan

hidrostatis yang dialami titik pada bejana juga semakin besar

tetapi sebaliknya jika luas penampang bejana semakin kecil

maka tekanan hidrostatis yang dialami titik pada bejana juga

4. semakin kecil.

Jika volume bejana semakin besar maka tekanan hidrostatis

yang dialami titik pada bejana juga semakin besar tetapi

sebaliknya jika volume bejana semakin kecil maka tekanan

hidrostatis yang dialami titik pada bejana juga semakin kecil.

Gaya yang dihasilkan berbanding terbalik dengan tekanan yang

5. $\quad$ diberikan. luas penampangnya.

Jika massa jenis benda lebih besar dari massa jenis fluida maka

6. benda akan melayang.

Jika massa jenis benda lebih besar dari massa jenis fluida makan benda akan mengapung.

Karena gaya yang diberikan terhadap $\mathrm{P}_{2}$ besar sehingga

tekanan yang dihasikan juga besar sebaliknya jika gaya yang

47

36,7

7. diberikan kecil maka tekanan yang dialami $\mathrm{P}_{1}$ kecil.

Karena gaya yang diberikan terhadap $\mathrm{P}_{2}$ kecil sehingga tekanan

yang dihasikan juga besar sebaliknya jika gaya yang diberikan

kecil maka tekanan yang dialami $\mathrm{P}_{1}$ besar.

Karena semakin dalam permukaan rawa, gaya apungnya

8. semakin besar.

Karena semakin dalam permukaan rawa, gaya apungnya semakin kecil.

Ketika di dalam air berat benda menjadi bertambah karena

9. $\quad$ massa benda yang besar dari massa jenis air.

Benda di dalam air dan di udara
dan udara tidak mempengaruhi.

41

Massa jenis benda pada posisi terapung, melayang dan

tenggelam sama.

10. Massa jenis benda pada keadaan terapung lebih kecil daripada

melayang dan tenggelam karena gaya apung berkurang seiring

bertambahnya massa jenis fluida.

Untuk mengetahui kemungkinan ada atau tidak perbedaan miskonsepsi antara laki-laki dan perempuan maka peneliti menggunakan uji chi kuadrat " Dalam uji chi kuadrat berlaku ketentuan apabila chi kuadrat hitung lebih kecil dari chi kuadrat tabel, maka $\mathrm{H}_{0}$ diterima dan apabila lebih besar atau sama dengan chi kuadrat tabel maka $\mathrm{H}_{0}$ ditolak (Daniati, 2016). Hipotesis yang diajukan adalah:

$\mathrm{H}_{0}$ : Tidak ada perbedaan miskonsepsi antara peserta didik laki-laki dan perempuan.

$\mathrm{H}_{\mathrm{a}}$ : Ada perbedaan miskonsepsi antara peserta didik laki-laki dan perempuan.

Berikut hasil chi kuadrat hitung keseluruhan peserta didik laki-laki dan perempuan yang mengalami miskonsepsi.

Tabel 3 Jumlah Peserta Didik Laki-laki dan Perempuan yang Mengalami Miskonsepsi

\begin{tabular}{|c|c|c|c|}
\hline \multirow{2}{*}{$\begin{array}{l}\text { No. } \\
\text { Soal }\end{array}$} & \multicolumn{2}{|c|}{ Gender } & \multirow{2}{*}{ Jumlah (X) } \\
\hline & $\mathrm{L}$ & $\mathrm{P}$ & \\
\hline 1 & 9 & 9 & 18 \\
\hline 2 & 19 & 24 & 43 \\
\hline
\end{tabular}

Edukatif : Jurnal Ilmu Pendidikan Vol 3 No 6 Tahun 2021 p-ISSN 2656-8063 e-ISSN 2656-8071 
4744 Analisis Miskonsepsi Menggunakan Four Tier Diagnostic Test Berbantuan Google Form pada Materi Tekanan Zat - Windi Oktaviani Putri, Haratua Tiur Maria, Hamdani

DOI: https://doi.org/10.31004/edukatif.v3i6.1445

\begin{tabular}{cccc}
\hline 3 & 16 & 15 & 31 \\
\hline 4 & 20 & 23 & 43 \\
\hline 5 & 17 & 13 & 30 \\
\hline 6 & 15 & 8 & 23 \\
\hline 7 & 27 & 29 & 56 \\
\hline 8 & 30 & 27 & 57 \\
\hline 9 & 19 & 24 & 43 \\
\hline 10 & 18 & 27 & 45 \\
\hline$Y$ & 190 & 199 & 389 \\
\hline
\end{tabular}

Tabel 4 Chi Kuadrat Hitung Peserta Didik Laki-Laki dan Perempuan

\begin{tabular}{|c|c|c|c|c|c|c|}
\hline Gender & No. Soal & $\mathrm{f}_{0}$ & $\mathrm{f}_{\mathrm{h}}$ & $f_{0}-f_{h}$ & $\left(f_{0}-f_{h}\right)^{2}$ & $\frac{\left(f_{0}-f_{h}\right)^{2}}{f h}$ \\
\hline \multirow{10}{*}{$\mathrm{L}$} & 1 & 9 & 8,8 & 0,21 & 0,04 & 0,005 \\
\hline & 2 & 19 & 21,0 & $-2,00$ & 4,01 & 0,191 \\
\hline & 3 & 16 & 15,1 & 0,86 & 0,74 & 0,049 \\
\hline & 4 & 20 & 21,0 & $-1,00$ & 1,01 & 0,048 \\
\hline & 5 & 17 & 14,7 & 2,35 & 5,51 & 0,376 \\
\hline & 6 & 15 & 11,2 & 3,77 & 14,18 & 1,263 \\
\hline & 7 & 27 & 27,4 & $-0,35$ & 0,12 & 0,005 \\
\hline & 8 & 30 & 27,8 & 2,16 & 4,66 & 0,167 \\
\hline & 9 & 19 & 21,0 & $-2,00$ & 4,01 & 0,191 \\
\hline & 10 & 18 & 22,0 & $-3,98$ & 15,84 & 0,720 \\
\hline \multirow{10}{*}{$\mathrm{P}$} & 1 & 9 & 9,2 & $-0,21$ & 0,04 & 0,005 \\
\hline & 2 & 24 & 22,0 & 2,00 & 4,01 & 0,182 \\
\hline & 3 & 15 & 15,9 & $-0,86$ & 0,74 & 0,046 \\
\hline & 4 & 23 & 22,0 & 1,00 & 1,01 & 0,046 \\
\hline & 5 & 13 & 15,3 & $-2,35$ & 5,51 & 0,359 \\
\hline & 6 & 8 & 11,8 & $-3,77$ & 14,18 & 1,205 \\
\hline & 7 & 29 & 28,6 & 0,35 & 0,12 & 0,004 \\
\hline & 8 & 27 & 29,2 & $-2,16$ & 4,66 & 0,160 \\
\hline & 9 & 24 & 22,0 & 2,00 & 4,01 & 0,182 \\
\hline & 10 & 27 & 23,0 & 3,98 & 15,84 & 0,688 \\
\hline \multicolumn{6}{|c|}{ JUMLAH } & 5,892 \\
\hline
\end{tabular}

Derajat kebebasan : $\mathrm{Dk}=(\mathrm{b}-1)(\mathrm{k}-1)$

$=(2-1)(10-1)$

$=9$

Dengan derajat kebebasan 9 dan taraf kesalahan yang digunakan yaitu 0,05, maka harga chi kuadrat tabel adalah 16,91. Berdasarkan hasil chi kuadrat hitung yang didapat yaitu 5,892 lebih kecil dari harga chi kuadrat tabel yitu 16,91, maka $\mathrm{H}_{0}$ diterima dan $\mathrm{H}_{\mathrm{a}}$ ditolak. Dapat disimpulkan tidak ada perbedaan miskonsepsi antara peserta didik laki-laki dan perempuan.

\section{Pembahasan}

\section{a. Profil Konsepsi Peserta Didik materi Tekanan Zat}

Berdasarkan hasil penelitian yang telah dilakukan diketahui persentase miskonsepsi tertinggi sebesar 45 $\%$ dan tergolong miskonsepsi kategori sedang. Terdapat pada soal nomor 8 dengan indikator mengidentifikasi pengaruh banyaknya zat cair pada kedudukan benda. Persentase peserta didik yang paham konsep paling besar terdapat pada soal nomor 9 dan 1, dengan persentase sebesar $43 \%$ dan $41 \%$ dengan indikator menentukan pengaruh massa jenis zat cair, percepatan gravitasi volume benda yang tercelup serta kedalaman benda terhadap gaya apung dan mengidentifikasi pengaruh luas penampang benda yang berbeda terhadap tekanan 
4745 Analisis Miskonsepsi Menggunakan Four Tier Diagnostic Test Berbantuan Google Form pada Materi Tekanan Zat - Windi Oktaviani Putri, Haratua Tiur Maria, Hamdani

DOI: https://doi.org/10.31004/edukatif.v3i6.1445

yang dihasilkan. Persentase rata-rata peserta didik yang paham konsep sebesar 32\% dan termasuk dalam kategori sedang. Sedangkan nilai rata-rata peserta didik yang mengalami miskonsepi sebesar $31 \%$ dan termasuk dalam kategori sedang.

Konsepsi yang ditemukan pada tiap indikator soal adalah sebagai berikut.

1. Mengidentifikasi Pengaruh Luas Penampang Benda yang Berbeda Terhadap Tekanan yang Dihasilkan.

Peserta didik yang miskonsepsi menganggap jika luas penampang benda berbanding lurus dengan tekanan yang diberikan benda tersebut. Peserta didik yang menganggap konsep ini benar berjumlah 18 orang atau $14,1 \%$. Temuan miskonsepsi ini sama seperti miskonsepsi yang ditemukan Mustikasari et al., ( 2017) yang menyatakan tekanan suatu benda dipengaruhi oleh luas permukaannya, semakin besar luas permukaan benda maka tekanan yang dihasilkan semakin besar. Peserta didik yang mengalami miskonsepsi juga menganggap jika luas penampang tidak mempengaruhi tekanan yang diberikan benda. Peserta didik yang menganggap konsep ini benar berjumlah 12 orang atau 9,4\%. Konsep yang benar adalah besar tekanan berbanding lurus dengan besarnya gaya dan berbanding terbalik dengan luas permukaannya (Guru, 2013). Peserta didik yang memiliki konsep benar berjumlah 96 orang atau $76,6 \%$.

2. Mengidentifikasi Pengaruh Massa Jenis Fluida terhadap Tekanan Hidrostatis.

Peserta didik yang miskonsepsi menganggap jika tekanan hidrostatis hanya bergantung pada massa jenis fluida. Peserta didik yang menganggap konsep ini benar berjumlah 20 orang atau 15,6\%. Peserta didik juga mengalami miskonsepsi menganggap jika tekanan hidrostatis hanya bergantung pada kedalaman titik di dalam fluida. Temuan miskonsepsi ini sama seperti miskonsepsi yang ditemukan Saifullah et al., (2016) yang menyatakan pada tekanan hidrostatis hanya dipengaruhi oleh kedalaman benda. Konsep yang benar yaitu tekanan hidrostatis adalah tekanan yang dilakukan zat cair dalam keadaan diam yang disebabkan oleh berat zat cair itu sendiri. Besarnya tekanan hidrostatis bergantung pada kedalaman titik dalam zat cair, massa jenis zat cair, dan percepatan zat cair (Listiyanti \& Marlupi, 2019). Peserta didik yang memiliki konsep benar berjumlah 66 orang atau $51,6 \%$.

3. Mengidentifikasi Pengaruh Volume Fluida Terhadap Tekanan Hidrostatis.

Peserta didik yang miskonsepsi menganggap jika volume fluida pada bejana mempengaruhi tekanan hidrostatis, volume fluida berbanding lurus dengan tekanan hidrostatis yang dihasilkan. Peserta didik yang menganggap konsep ini benar berjumlah 21 orang atau 16,4\%. Temuan miskonsepsi ini sama seperti miskonsepsi yang ditemukan Harmania et al., (2019) yang menyatakan semakin banyak volume air pada suatu wadah maka tekanan hidrostatinya semakin besar. Peserta didik yang mengalami miskonsepsi juga menganggap jika luas penampang mempengaruhi tekanan hirostatis, luas penampang berbanding lurus dengan tekanan hidrostatis. Peserta didik yang menganggap konsep ini benar berjumlah 28 orang atau 21,9\%. Konsep yang benar adalah besarnya tekanan hidrostatis bergantung pada kedalaman titik dalam zat cair, massa jenis zat cair, dan percepatan zat cair (Listiyanti \& Marlupi, 2019). Kedalaman bejana berbanding lurus dengan tekanan hidrostatis yang dihasilkan. Peserta didik yang memiliki konsep benar berjumlah 79 orang atau $61,7 \%$.

4. Mengidentifikasi Hubungan Tekanan Hidrostatis dengan Luas Penampang Wadah dan Ukuran Benda.

Peserta didik yang miskonsepsi menganggap jika volume fluida pada bejana mempengaruhi tekanan hidrostatis, volume fluida berbanding lurus dengan tekanan hidrostatis yang dihasilkan. Peserta didik yang menganggap konsep ini benar berjumlah 30 orang atau 23,4\%. Peserta didik yang mengalami miskonsepsi juga menganggap jika luas penampang mempengaruhi tekanan hirostatis, luas penampang berbanding lurus dengan tekanan hidrostatis. Peserta didik yang menganggap konsep ini benar berjumlah 45 orang atau 35,2\%. Konsep yang benar adalah besarnya tekanan hidrostatis bergantung pada kedalaman titik dalam zat cair, massa jenis zat cair, dan percepatan zat cair (Listiyanti \& Marlupi, 2019). Kedalaman bejana sebanding dengan tekanan hidrostatis yang dihasilkan. Peserta didik yang memiliki konsep benar berjumlah 53 orang atau $41,4 \%$. 
4746 Analisis Miskonsepsi Menggunakan Four Tier Diagnostic Test Berbantuan Google Form pada Materi Tekanan Zat - Windi Oktaviani Putri, Haratua Tiur Maria, Hamdani

DOI: https://doi.org/10.31004/edukatif.v3i6.1445

5. Mengidentifikasi Hubungan Antara Gaya dan Luas Penampang pada Bejana Berhubungan.

Peserta didik yang miskonsepsi menganggap jika gaya yang dihasilkan pada hukum pascal berbanding terbalik dengan tekanan yang diberikan. Peserta didik yang menganggap konsep ini benar berjumlah 56 orang atau 43,8\%. Peserta didik yang mengalami miskonsepsi juga menganggap jika gaya yang dihasilkan berbanding terbalik dengan hambatan luas penampangnya. Peserta didik yang menganggap konsep ini benar berjumlah 25 orang atau $19,5 \%$. Konsep yang benar adalah hubungan gaya dan luas penampang adalah berbanding lurus, semakin kecil luas penampang maka gaya yang diperlukan untuk menekan juga semakin kecil (Serway \& Jewett, 2009). Peserta didik yang memiliki konsep benar berjumlah 47 orang atau 36,7\%.

6. Menentukan Posisi Benda Jika Massa Jenis Benda Berbeda.

Peserta didik yang miskonsepsi menganggap benda akan melayang jika massa jenis benda lebih besar dari massa jenis fluida. Peserta didik yang menganggap konsep ini benar berjumlah 48 orang atau 37,5\%. Peserta didik yang mengalami miskonsepsi juga menganggap benda akan mengapung jika massa jenis benda lebih besar dari massa jenis fluida. Peserta didik yang menganggap konsep ini benar berjumlah 22 orang atau 17,2\%. Konsep yang benar adalah jika massa jenis benda lebih besar dari massa jenis fluida, maka gaya apung ke atas menjadi lebih kecil dari pada gaya gravitasi, dan menyebabkan benda tenggelam (Serway \& Jewett, 2009). Peserta didik yang memiliki konsep benar berjumlah 58 orang atau 45,3\%.

7. Mengidentifikasi Hubungan Antara Tekanan dan Luas Penampang pada Bejana Berhubungan.

Peserta didik yang mengalami miskonsepsi menganggap gaya yang diberikan terhadap $\mathrm{P}_{2}$ besar sehingga tekanan yang dihasikan juga besar sebaliknya jika gaya yang diberikan kecil maka tekanan yang dialami $\mathrm{P}_{1}$ kecil. Peserta didik yang menganggap konsep ini benar berjumlah 47 orang atau 36,7\%. Peserta didik yang miskonsepsi juga menganggap gaya yang diberikan terhadap P2 kecil sehingga tekanan yang dihasikan juga besar sebaliknya jika gaya yang diberikan kecil maka tekanan yang dialami P1 besar. Peserta didik yang memiliki konsep ini berjumlah 33 orang atau 25,8\%. Konsep yang benar adalah jika massa jenis benda lebih besar dari massa jenis fluida, maka gaya apung ke atas menjadi lebih kecil dari pada gaya gravitasi, dan menyebabkan benda tenggelam (Serway \& Jewett, 2009). Peserta didik yang memiliki konsep benar berjumlah 58 orang atau $45,3 \%$.

8. Mengidentifikasi Pengaruh Banyaknya Zat Cair pada Kedudukan Benda.

Peserta didik yang miskonsepsi menganggap kedalaman air mempengaruhi gaya apung, kedalaman air berbanding lurus dengan gaya apung. Peserta didik yang menganggap konsep ini benar berjumlah 41 orang atau $32 \%$. Peserta didik yang mengalami miskonsepsi juga menganggap kedalaman air berbanding terbalik dengan gaya apung. Peserta didik yang menganggap konsep ini benar berjumlah 31 orang atau 24,2\%. Konsep yang benar adalah suatu benda yang dicelupkan sebagian atau seluruhnya ke dalam zat cair akan mengalami gaya ke atas ya besarnya sama dengan berat zat cair yang dipindahkan oleh benda tersebut (Giancoli C. Dauglas, 2014). Gaya angkat atau gaya apung tidak dipengaruhi oleh kedalaman air. Peserta didik yang memiliki konsep benar berjumlah 56 orang atau $43,8 \%$.

9. Mengidentifikasi Pengaruh Massa Jenis Fluida pada Gaya Apung

Peserta didik yang miskonsepsi menganggap ketika di dalam air berat benda akan menjadi bertambah karena massa benda yang besar dari massa jenis air. Peserta didik yang menganggap konsep ini benar berjumlah 35 orang atau $27,3 \%$. Peserta didik yang mengalami miskonsepsi juga menganggap massa jenis air dan udara tidak mempengaruhi berat benda, berat benda di dalam air dan udara sama. Peserta didik yang menganggap konsep ini benar berjumlah 22 orang atau 17,2\%. Konsep yang benar adalah benda menjadi lebih ringan bila diukur dalam air daripada di udara karena di dalam air benda mendapat gaya ke atas. Ketika di udara, benda memiliki berat mendekati yang sesungguhnya (Nurmanitari, 2020). Peserta didik yang memiliki konsep benar berjumlah 71 orang atau 55,5\%.

10. Menentukan Pengaruh Massa Jenis Zat Cair, Percepatan Gravitasi, Volume Benda yang Tercelup serta

Kedalaman Benda Terhadap Gaya Apung. 
Peserta didik yang miskonsepsi menganggap massa jenis benda pada posisi terapung, melayang, dan tenggelam sama. Peserta didik yang menganggap konsep ini benar berjumlah 29 orang atau 22,7\%. Peserta didik yang mengalami miskonsepsi juga menganggap massa jenis benda pada keadaan terapung lebih kecil daripada melayang dan tenggelam karena gaya apung berkurang seiring bertambahnya massa jenis fluida. Peserta didik yang menganggap konsep ini benar berjumlah 40 orang atau 31,3\%. Konsep yang benar adalah bahwa besarnya gaya angkat ke atas atau gaya apung yang dialami benda di dalam fluida bergantung pada massa jenis fluida, volume fluida yang dipindahkan dan percepatan gravitasi bumi. Massa jenis fluida sebanding dengan gaya apung yang dihasilkan, semakin besar massa jenis fluida maka gaya apung yang dihasilkan akan semakin besar (Saripudin, 2018). Peserta didik yang memiliki konsep benar berjumlah 59 orang atau $41,6 \%$.

\section{b. Perbedaan Miskonsepsi Peserta Didik Laki-Laki dan Perempuan}

Riset pendidikan mengenai perbedaan gender dalam mempelajari matematika dan sains telah banyak dilakukan di tahun 1980-an hingga tahun 2001 yang menunjukkan dominasi laki-laki dalam matematika dan sains. Namun, setelah itu banyak penelitian yang menunjukkan hasil berbeda, yaitu ditemukan bahwa perbedaan gender tidak berperan dalam kesuksesan belajar, dalam arti tidak dapat disimpulkan dengan jelas apakah laki-laki atau perempuan lebih baik dalam belajar matematika dan fakta menunjukkan bahwa ada banyak perempuan yang sukses dalam karir matematikanya. Perbedaan prestasi belajar peserta didik laki-laki dan perempuan lebih disebabkan oleh perbedaan tingkat inteligensi (Pambudiono et al., 2013).

Berdasarkan penelitian yang telah dilakukan chi kuadrat hitung miskonsepsi peserta didik laki-laki dan peserta didik perempuan diketahui bahwa nilai chi kuadrat hitung yaitu 5,892. Dengan hasil harga tabel chi kuadrat hitung $(5,892)$ lebih kecil dari harga chi kuadrat tabel $(16,919)$ berdasarkan syarat uji chi kuadrat maka $\mathrm{H}_{0}$ diterima dan $\mathrm{H}_{\mathrm{a}}$ ditolak. Kesimpulannya yaitu tidak ada perbedaan miskonsepsi peserta didik lakilaki dan perempuan. Hasil penelitian ini diperkuat dengan penelitian yang dilakukan oleh Daniati et al.,( n.d.) tentang Miskonsepsi Peserta Didik pada Materi Listrik Statis bahwa tidak ada perbedaan miskonsepsi yang dialami peserta didik laki-laki dan perempuan. Hasil penelitian ini juga diperkuat dengan penelitian sebelumnya yang dilakukan oleh Safitri et al.,( 2020) tentang Identifikasi Miskonsepsi peserta didik pada Materi Kalor dan Perpindahannya di Kelas VII SMP yang menyatakan bahwa tidak ada perbedaan proporsi miskonsepsi antara peserta didik laki-laki dan perempuan pada pembelajaran fisika materi suhu dan kalor, jadi antara peserta didik laki-laki dan perempuan memiliki peluang yang sama mengalami miskonsepsi dalam mempelajari materi tersebut. Adapun perbedaan yang dapat dilihat dalam proses pembelajaran antara peserta didik laki-laki dan peserta didik perempuan adalah perbedaan dari segi karakternya. Beberapa penelitian mengenai jenis kelamin menunjukkan bahwa lebih banyak persamaan daripada perbedaan dalam kemampuan kognitif antara laki-laki dan perempuan.

\section{KESIMPULAN}

Berdasarkan data hasil penelitian dan pembahasan, secara umum dapat disimpulkan bahwa hasil miskonsepsi paling tinggi sebesar $45 \%$, sedangkan miskonsepsi terendah sebesar $14 \%$. Nilai rata-rata peserta didik yang mengalami miskonsepsi sebesar $30 \%$ dan termasuk dalam kategori rendah. Secara khusus hasil penelitian dan pembahasan dapat disimpulkan berikut ini:

1. Berdasarkan hasil analisis konsepsi ditemukan profil konsepsi sebagai berikut:

a. Konsepsi yang Benar yaitu: (1) Luas penampang pada benda berbanding terbalik dengan tekanan yang dihasilkan $(76,6 \%)$; (2) Tekanan hidrostatis bergantung pada massa jenis fluida, percepatan gravitasi yang dialami titik, dan kedalaman titik di dalam fluida (51,6\%); (3) Kedalaman benda berbanding lurus dengan tekanan hidrostatis yang dialami benda $(61,7 \%)$; (4) Kedalaman benda berbanding lurus dengan tekanan hidrostatis yang dialami benda (41,4\%); (5) Gaya yang dihasilkan berbanding lurus dengan tekanan 
4748 Analisis Miskonsepsi Menggunakan Four Tier Diagnostic Test Berbantuan Google Form pada Materi Tekanan Zat - Windi Oktaviani Putri, Haratua Tiur Maria, Hamdani

DOI: https://doi.org/10.31004/edukatif.v3i6.1445

yang diberikan (36,7\%); (6) Massa jenis benda lebih besar dari massa jenis fluida maka benda akan tenggelam (45,3\%); (7) Tekanan yang bekerja pada fluida di dalam wadah tertutup akan diteruskan oleh fluida tersebut kesegala arah dengan sama besar (37,5\%); (8) Gaya apung tidak bergantung pada kedalaman air (43,8\%); (9) Ketika di dalam air berat benda menjadi berkurang karena benda mendapatkan gaya ke atas (gaya apung) oleh zat cair (55,5\%); (10) Besarnya gaya apung bertambah seiring bertambahnya massa jenis fluida $(46,1 \%)$.

b. Konsepsi yang Tidak Benar yaitu : (1) Luas penampang pada benda sebanding dengan tekanan yang dihasilkan (14,1\%); (2) Luas penampang pada benda tidak mempengaruhi tekanan yang dihasilkan $(9,4 \%)$; (3) Tekanan hidrostatis hanya bergantung pada massa jenis fluida (15,6\%); (4) Tekanan hidrostatis hanya bergantung pada kedalaman titik di dalam fluida (32,8\%); (5) Luas penampang bejana berbanding lurus dengan tekanan hidrostatis yang dialami benda (21,9\%); (6) Volume benda berbanding lurus dengan tekanan hidrostatis yang dialami benda $(16,4 \%)$; (7) Luas penampang bejana berbanding lurus dengan tekanan hidrostatis yang dialami benda $(35,2 \%)$; (8) Volume benda berbanding lurus dengan tekanan hidrostatis yang dialami benda (23,4\%); (9) Gaya yang dihasilkan berbanding terbalik dengan tekanan yang diberikan (43,8\%); (10) Gaya yang dihasilkan berbanding terbalik dengan hambatan luas penampangnya (19,5\%); ( 11) Massa jenis benda lebih besar dari massa jenis fluida maka benda akan melayang (37,5\%); (12) Massa jenis benda lebih besar dari massa jenis fluida makan benda akan mengapung (17,2\%); (13) Gaya yang diberikan terhadap P2 besar sehingga tekanan yang dihasikan juga besar sebaliknya jika gaya yang diberikan kecil maka tekanan yang dialami P1 kecil (36,7\%); (14) Gaya yang diberikan terhadap P2 kecil sehingga tekanan yang dihasikan juga besar sebaliknya jika gaya yang diberikan kecil maka tekanan yang dialami P1 besar (25,8\%); (15) Gaya apung berbanding lurus dengan kedalaman fluida (32\%); (16) Gaya apung berbanding terbalik dengan kedalaman fluida $(24,2 \%)$; (17) Ketika di dalam air berat benda menjadi bertambah karena massa benda yang besar dari massa jenis air (27,3\%); (18) Benda di dalam air dan di udara sama karena massa jenis air dan udara tidak mempengaruhi (17,2\%); (19) Massa jenis benda pada posisi terapung, melayang dan tenggelam sama (22,7\%); (20) Massa jenis benda pada keadaan terapung lebih kecil daripada melayang dan tenggelam karena gaya apung berkurang seiring bertambahnya massa jenis fluida $(31,3 \%)$.

2. Tidak ada perbedaan miskonsepsi antara peserta didik laki-laki dan perempuan. Dengan nilai chi kuadrat hitung $(5,892)$ lebih kecil dari nilai chi kuadrat tabel $(16,919)$.

\section{DAFTAR PUSTAKA}

Arifin, Z. (2017). Mengembangkan Instrumen Pengukur Critical Thinking Skills Siswa Pada Pembelajaran Matematika Abad 21. Theorems (The Original Research Of Mathematics), 1(2).

Daniati, S., Djudin, T., \& Hamdani, H. (N.D.). Miskonsepsi Siswa Pada Materi Listrik Statis Di Kelas Xii Sma Negeri 9 Pontianak. Jurnal Pendidikan Dan Pembelajaran Khatulistiwa, 7(1).

Elisa, E., Mardiyah, A., \& Ariaji, R. (2017). Peningkatan Pemahaman Konsep Fisika Dan Aktivitas Mahasiswa Melalui Phet Simulation. Peteka, 1(1), 15-20.

Giancoli C. Dauglas. (2014). Fisika Jilid I. Erlangga.

Guru, B. (2013). Ilmu Pengetahuan Alam. Jakarta: Kementerian Pendidikan Dan Kebudayaan.

Harmania, A., Aisyah, \& Patandean, A. J. (2019). Miskonsepsi Materi Fluida Statis Pada Peserta Didik Kelas $\mathrm{Xi}$ Mia 7 Sma Negeri 1 Gowa. Prosiding Seminar Nasional Fisika, 2. Https://Ojs.Unm.Ac.Id/Semnasfisika/Article/View/12885.

Irmaya, F. P., \& Sunarti, T. (2020). Validitas Instrumen Penilaian Berbantuan Google Form Untuk Mengukur Kemampuan Berpikir Kreatif Fisika Pada Bahasan Fluida Dinamis. Inovasi Pendidikan Fisika, 9(2).

Listiyanti, L., \& Marlupi. (2019). Ipa Ilmu Pengetahuan Alam Untuk Smp/Mts Kelas Vii Semester 2. Cv. Absolut Media.

Mahanal, S. (2012). Strategi Pembelajaran Biologi, Gender Dan Pengaruhnya Terhadap Kemampuan Berpikir Kritis. Prosiding Seminar Biologi, 9(1). 
4749 Analisis Miskonsepsi Menggunakan Four Tier Diagnostic Test Berbantuan Google Form pada Materi Tekanan Zat - Windi Oktaviani Putri, Haratua Tiur Maria, Hamdani

DOI: https://doi.org/10.31004/edukatif.v3i6.1445

Mustikasari, V. R., Miftakhul, A., \& Munzil. (2017). Identifikasi Miskonsepsi Konsep Tekanan Zat Siswa Kelas Viii-C Smpn 1 Karangploso Semester Genap Tahun Pelajaran 2017-2018. Jurnal Pembelajaran Sains, 1(2). Https://Doi.Org/Http://Dx.Doi.Org/10.17977/Um033v1i2p39-50.

Nurmanitari, P. (2020). Identifikasi Miskonsepsi Menggunakan Three-Tier Diagnostic Test Berbasis Google Form Materi Tekanan Zat Dan Penerapannya Pada Masa Pandemi Covid-19 Di Smp Negeri 4 Salatiga [Institut Agama Islam Negeri Salatiga]. Http://E-Repository.Perpus.Iainsalatiga.Ac.Id/Id/Eprint/9340.

Nurulwati, N., \& Rahmadani, A. (2019). Perbandingan Hasil Diagnostik Miskonsepsi Menggunakan Threetier Dan Fourtier Diagnostic Test Pada Materi Gerak Lurus. Jurnal Pendidikan Sains Indonesia (Indonesian Journal Of Science Education), 7(2), 101-110.

Pambudiono, A., Zubaidah, S., \& Mahanal, S. (2013). Perbedaan Kemampuan Berpikir Dan Hasil Belajar Biologi Siswa Kelas X Sma Negeri 7 Malang Berdasarkan Jender Dengan Penerapan Strategi Jigsaw. Jurnal Pendidikan Hayati, 1(1), 1-10.

Safitri, N. S., Djudin, T., \& Trisianawati, E. (2020). Identifkasi Miskonsepsi Siswa Pada Materi Kalor Dan Perpindahannya Di Kelas Vii Smp Negeri 5 Sungai Kakap. Jurnal Pendidikan Sains Dan Aplikasinya, $3(1), 1-6$.

Saifullah, S., Mantinu, A., \& Wartono. (2016). Identifikasi Miskonsepsi Siswa Kelas X Pada Materi Fluida Statis Dengan Instrumen Diagnostik Three-Tier. Jurnal Pendidikan Dan Pembelajaran, 3(1). Http://Journal.Um.Ac.Id/Index.Php/Pendidikan-Dan-Pembelajaran/Article/View/10148.

Saripudin, A. (2018). Praktis Belajar Fisika Untuk Kelas X. Edusoftware.

Serway, R. A., \& Jewett, J. W. (2009). Fisika Untuk Sains Dan Teknik. Salemba Teknik.

Sheftyawan, W. B., Prihandono, T., \& Lesmono, A. D. (2018). Identifikasi Miskonsepsi Siswa Menggunakan Four-Tier Diagnostic Test Pada Materi Optik Geometri. Jurnal Pembelajaran Fisika, 7(2), 147-153.

Sugiyono. (2013). Metode Penelitian Pendidikan Pendekatan Kuantitatif, Kualitatif, Dan R\&D. Alfabeta.

Sugiyono. (2015). Metode Penelitian Kuantitatif, Kualitatif, Dan R\&D. Alfabeta.

Suwarna, I. P. (2013). Analisis Miskonsepsi Siswa Sma Kelas X Pada Mata Pelajaran Fisika Melalui Cri (Certainty Of Response Index) Termodifikasi. 